Broft, R.D., and Koskela, L. (2018). "Supply Chain Management in Construction from a Production Theory Perspective." In: Proc. $26^{\text {th }}$ Annual Conference of the International Group for Lean Construction (IGLC), González, V.A. (ed.), Chennai, India, pp. 271-281. DOI: doi.org/10.24928/2018/0538. Available at: www.iglc.net.

\title{
SUPPLY CHAIN MANAGEMENT IN CONSTRUCTION FROM A PRODUCTION THEORY PERSPECTIVE
}

\author{
Rafaella D. Broft ${ }^{1}$, and Lauri Koskela ${ }^{2}$
}

\begin{abstract}
Production management in construction is moving away from conventional construction management. The correctives to this model have been explicitly or implicitly based on flow and value principles. Supply Chain Management (SCM) is often presented as suitable for efficient management of construction production, but its successful implementation in the industry remains limited, particularly at the lower tiers of the construction supply chain. This paper takes a closer look at SCM - an analysis from the production perspective might help to create a better understanding of the concept and the key principles presented could be prescriptive in the further development of SCM in construction.
\end{abstract}

\section{KEYWORDS}

Construction management, supply chain management, production theory, key principles.

\section{INTRODUCTION}

Despite the successful examples of Supply Chain Management (SCM) initiatives at the higher tiers of the construction supply chain, relationships at the lower tiers seem to remain traditional and the SC Maturity of construction firms continues to be low (Broft et al., 2016). The quality of a main contractor-supplier relationship affects the main contractors' ability to perform on projects (Kale \&Arditi, 2001). The increasing percentage of project turnover which is spent on buying goods and services provides opportunities for contractor-supplier collaboration, and emphasises the importance and significance of managing suppliers (Bemelmans et al., 2012). Main contractors are willing to develop closer relationships, but implementing SCM seems a long-term, complex process and requires a certain level of understanding and therefore learning throughout the supply chain (Broft et al., 2016). In the last decades, various supply chain concepts have emerged in parallel in generic theory and manufacturing practice - all

1 PhD Candidate, The Bartlett School of Construction and Project Management, University College London, United Kingdom, r.d.broft@gmail.com

2 Professor, School of Art, Design and Architecture, University of Huddersfield, United Kingdom, 1.koskela@hud.ac.uk 
highly related, leading to a high ambiguity between the definitions of the different concepts and reflecting the cross-functional nature of SCM (Ellram\& Cooper, 2014).

This paper takes a closer look at SCM as an alternative for efficient management of construction production. An analysis from the production perspective might help to create a better understanding of the concept, which is seen as a corrective to the conventional construction management model, dominated by the transformation concept (Koskela, 2000) - discussion exists whether SCM is based on flow or value principles.

\section{CONSTRUCTION FROM A PRODUCTION PERSPECTIVE}

"Production is the action of making or manufacturing from components or raw materials, or the process of being so manufactured" (Oxford Dictionaries, 2018).

Production has three kinds of goals - besides the general goal of getting intended products produced, there are internal goals related to the characteristics of the production itself (i.e. cost minimisation and level of utilisation) and external goals related to the needs of the customer (i.e. quality, dependability and flexibility) (Koskela, 1999). Production theory and practice has sprung from thinking about repetitive manufacturing it has essentially been theory about making (Ballard, 2005). Three different conceptualisations of production have been used in practice and conceptually advanced in the $20^{\text {th }}$ century (Table 1 ) - each of them captures an intrinsic phenomenon of production (Koskela, 2000).

Table 1: Transformation, flow and value views on production (Koskela, 2000)

\begin{tabular}{|c|c|c|c|}
\hline $\begin{array}{c}\text { Transformation } \\
\text { view } \\
\text { of production }\end{array}$ & $\begin{array}{c}\text { As a transformation } \\
\text { of inputs into } \\
\text { outputs }\end{array}$ & $\begin{array}{c}\text { As a flow of material, } \\
\text { composed of inspection, } \\
\text { moving, waiting and } \\
\text { trans-formation }\end{array}$ & $\begin{array}{c}\text { As a process where } \\
\text { value for the customer } \\
\text { is created through } \\
\text { fulfilment of his } \\
\text { requirements }\end{array}$ \\
\hline Main principles & $\begin{array}{c}\text { Getting production } \\
\text { realised efficiently }\end{array}$ & $\begin{array}{c}\text { Elimination of waste } \\
\text { (non-value-adding } \\
\text { activities) }\end{array}$ & $\begin{array}{c}\text { Elimination of value } \\
\text { loss }\end{array}$ \\
\hline
\end{tabular}

\section{THE PRODUCTION-RELATED CHARACTERISTICS OF CONSTRUCTION}

In construction, a supply chain shows the following production-related characteristics:

- Converging logistics to a common and fixed point in the supply chain: the construction site where the 'construction factory' is located (Luhtala et al., 1994);

- Temporary and non-repetitive, or in other words, one-off construction projects that are produced through repeated reconfiguration of project organisations (Vrijhoef \& Koskela, 2000) - construction is prototype production;

- Multiple and concurrent projects (Souza de Souza, 2015);

- A number of studies have linked construction with the characteristics of the Engineer-to-order (ETO) production strategy - ETO-projects are described as 
having high levels of customisation and typically managed on a project basis (Gosling et al., 2012).

- Construction is mainly based on two types of processes: small batch process and job process (Krajewski et al., 2007);

- One location can be worked on by several work stations at the same time and work is carried out in suboptimal conditions, with lessened productivity (Koskela, 1999).

\section{THE PECULIARITIES OF CONSTRUCTION}

The characteristics of construction are often seen as peculiarities of the industry, preventing the attainment of flows as efficient as in manufacturing (Koskela, 1999).These peculiarities are considered to differentiate between project-based industries and repetitive manufacturing, where SCM was born (Elfving\& Ballard, in press). Despite the fact that other types of production also possess one or several of these characteristics, it is the combination of properties that defines construction 'peculiar' (Ballard \& Howell, 1998) - construction objects possess two characteristics which together uniquely define them: (1) they belong to the category "fixed position manufacturing", and (2) they are rooted in place. The objects of fixed position manufacturing are wholes assembled from parts. In the assembly process, the parts become too large to move through assembly stations, so the stations move through the emerging wholes, adding pieces as they move. Some degree of site production, at minimum the final assembly, is a necessary aspect of construction. This rootedness-in-place brings with it uncertainty and differentiation (Ballard \& Howell, 1998).

The organisation of production and the supply chains is strongly adapted to these basic characteristics (Koskela, 2000; Broft, 2017).

\section{CONSTRUCTION MANAGEMENT FROM A PRODUCTION PERSPECTIVE}

The construction industry, both theoretically and in practice, has been dominated by the transformation concept (Koskela, 2000) with three main features: (1) a sequential method of project realisation where design and construction are separated, (2) procurement through bidding; and, (3) segmented control with institutionalised roles and division of work. This conventional model was criticised for its centralised and formal management, as this does not recognise the uncertainty of and interdependence between the operations of the construction process (Tavistock Institute, 1966). The correctives to the conventional model have been explicitly or implicitly based on flow (i.e. Design-Build and lean construction) and value principles (i.e. quality management). One of these correctives, SCM, can be seen as an alternative for realising efficient construction management.

\section{PRODUCTION THEORY: SCM IN CONSTRUCTION}

In construction, SCM is often seen as a project-specific approach (Green et al., 2005). Main contractors have a central position in the management of supply chains (Pryke, 2009) - it is believed that main contractors have more influence on the organisation of the 
project and on the performance and quality of the work of its suppliers. However, implementation of SCM by main contractors is relatively slow (Green et al., 2005). This section analyses the concept from the different production theory perspectives.

\section{FROM A TRANSFORMATION PERSPECTIVE}

Production can be seen as a transformation of inputs into outputs, or in other words, as the transformation of one set of resources into a second set (Grubbström, 1995). The total transformation process can be decomposed into subprocesses, which are smaller, more manageable transformation processes (Koskela, 2000) - production management equates to carrying out these 'tasks' as efficiently as possible. Every process exists of any activity or group of activities that takes one of more inputs, transforms them, and provides one or more outputs to its customers (Krajewski et al., 2007).

As a consequence of the uncertainty faced by main contractors in obtaining continuous work and the need to accommodate the different, increasingly specialised and complex, requirements of each project (Tam et al., 2011), most of the subprocesses known in a construction supply chain are outsourced or subcontracted to specialist organisations, suppliers (Broft et al., 2016), focusing on the production of a specific subprocess (Figure 1).As a result, the main contractor, the principal construction organisation that manages a construction project, executes only a small part of the product by its own personnel and its own production facilities (Dubois \& Gadde, 2000).

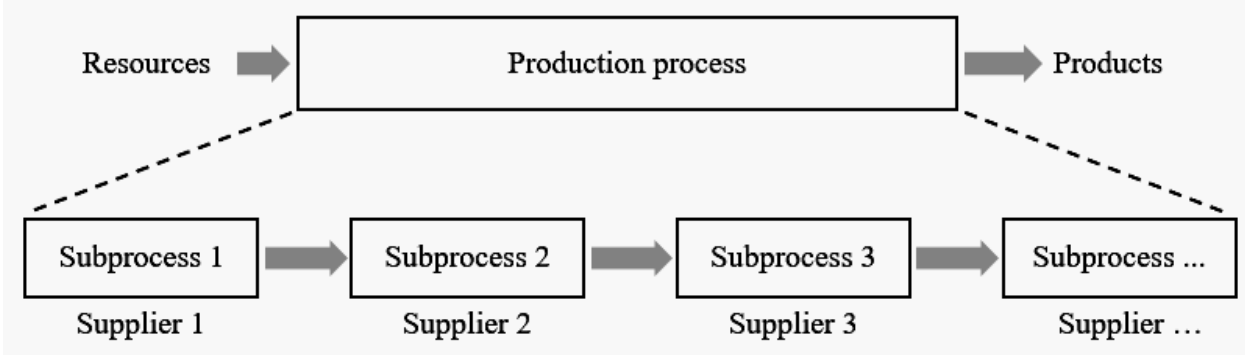

Figure 1: Decomposition of a production process in a supply chain (adapted from Koskela, 2000; p.42)

From a transformation perspective, subprocesses are considered independent from each other and subsequently, the cost of the total process can be minimised by minimising the cost of each subprocess. In order to get every new construction project executed to the lowest possible cost (Eriksson, 2015), competitive pricing is promoted through procurement strategies often pursued by clients, featuring purchasing transactions (Gadde \& Dubois, 2010) and favouring the lowest bidder. Contractually, main contractors are responsible for the construction of projects, but they rely on suppliers to execute the works (Clarke \& Herrmann, 2004) - they do this to reduce their overhead and operating costs, improve efficiency, and achieve a more economic delivery of projects (Arditi \& Chotibhongs, 2005). As part of task management, all these subprocesses (or effectively suppliers), and the costs involved need to be managed. SCM offers an alternative way for this production management, involving the control and optimisation of decomposed and subcontracted activities, where suppliers are invited to focus on the efficiency of their subprocess (through, i.e., standardisation and 
prefabrication) and to eliminate unnecessary costs (with the help of the production manager).

Here, a supply chain is defined as a set of three or more entities (organisations or individuals) directly involved in the upstream and downstream focus of products, services, finances and/or information from a to a customer (and in reverse) (Mentzer et al., 2001). SCM, using a process orientation (Ellram \& Cooper, 2014), considers the supply chain as a means for linking structured activities designed to produce an output for a particular customer or market, and a means to improve and/or coordinate processes. It looks at activities, where activities could be seen as a single element of a process (Burgess et al., 2006), or processes versus the relationships in supply chains. As a result of the fragmentation and prevalent competitive tendering, construction supply chains are disjointed (Eriksson, 2015). This means that current construction practice, where the relationship with suppliers is considered to be exclusively transactional, with no relational component (Elfving \& Ballard, in press), fits the transformation perspective. SCM from the transformation perspective considers these relationships. As opposed to transaction cost economics (TCE) that treats each transaction separately (make-or-buy), SCM includes the systems benefits of organising clusters of related transactions as supply chains are introduced - related transactions are grouped and managed as chains (Williamson, 2008). SCM could then involve elements such as the creation of a more permanent production process through long-term relationships with suppliers. This offers alternative ways of minimising (transaction) costs (Pasquire et al., 2015).

\section{FROM A FLOW PERSPECTIVE}

When production is depicted as a flow of material, the flow consists of four stages: processing, inspection, moving and waiting (Gilbreth \& Gilbreth, 1922). These transformation and non-transformation activities both consume time from the point of view of the product - the amount of time consumed by the total transformation and its parts or subprocesses plays an important role in the flow conceptualisation (Koskela, 2000). For this reason, production management tries to shorten the total time by eliminating non-value adding phenomena or waste from the production process (Shingo, 1988). In other words, production management involves the management of flow. It minimises the share of non-transformation stages of the production flow, especially by reducing variability as variability increases the lead time. There are two types of variability in flows of production: process-time variability which refers to the time required to process a task at one workstation, and flow variability meaning the variability of the arrival of jobs to a single workstation (Hopp \& Spearman, 1996).

From a flow perspective, the object of SCM is "to integrate and manage the sourcing, flow and control of materials using a total system perspective across multiple functions and multiple tiers of suppliers" (Mentzer et al., 2001). A supply chain, encompassing all the subprocesses (as explained and visualised in Section 3.1), is conceptualised as a production flow (rather than a series of transactions or contracts) - it covers the flow of goods from the different suppliers through manufacturing and distribution chains to the end user (Christopher, 2005). 
A manufacturing system, which involves the flow of material through a plant - is an objective-oriented network of processes through which entities (the parts to be manufactured) flow (Hopp \& Spearman, 1996). Besides the flow of materials, construction knows two other flows: location flow and assembly flow, which are related to the characteristics of construction as described in Section 2.1 and 2.2: Production in construction is of assembly-type, where different material flows are connected to the end product on-site. Due to the size of the product of construction, an intermediate workflow arises where all installation locations proceed through the installation work station (Koskela, 2000). Whilst conventional construction management focuses on the project, SCM emphasises the product and the tasks or subprocesses organised around this product as a network - the realisation of tasks heavily depends on flows, and the progress of flows in turn is dependent on the realisation of tasks (Koskela, 1999). Coordination between subprocesses or supply chain partners is important in order to boost total process efficiency and effectiveness across members of the supply chain (Lambert et al., 1998).

SCM from the flow perspective acknowledges the interdependency between subprocesses and includes integration. The current approach in construction might still be sequential, but SCM in construction should be seen as the management of a network of interconnected organisations that are involved in the different processes and activities that produce products and services to the customer (Dainty et al., 2001; Christopher, 2005). Owing to the still disconnected processes and the large number of suppliers, main contractors are needed to coordinate operations to provide focus and integration of the varied parts (Akintan \& Morledge, 2013): SCM is "the task of integrating organisational units along a supply chain and coordinating materials, information and financial flows in order to fulfil customer demand with the aim of improving competitiveness of a supply chain as a whole" (Stadler, 2000). This integration between subprocesses focuses, from the flow perspective, on the overall efficiency of the entire supply chain, through the use of important flow-related principles - the reduction of the lead time of the product through the elimination of waste within the overall production process and the reduction of variability(Berliner \& Brimson, 1988; Koskela, 2000). It equals to the synchronisation of a firm's processes with those of its suppliers and customers to match the flow of materials, services, and information with customer demand (Krajewski et al., 2007).

\section{FROM A VALUE PERSPECTIVE}

Production can also be seen as a means for the fulfilment of the customer needs. Production management equates to translating these needs accurately into a design solution and then producing products that conform to the specified design. This concept reflects the importance of a focus on value. In construction, the attitude tends to be oriented towards conformance to contractual specifications rather than gaining additional financial benefits or competitive strength from quality improvement (Vrijhoef, 2011). As a result, construction seems oriented more towards production and getting the work done on time and within budget (Lai \& Cheng, 2003) - the project success measure is cost, and completing the project by the scheduled date is generally the most important scheduling objective (Tukel \& Rom, 1998). 
SCM involves the integration of key business processes from the end user through original suppliers that provide products, services, and information that add value for customers and other stakeholders (Lambert et al., 1998). Value creation has become a function of the network of iterative and transient relationships between actors that are connected - construction projects are essentially about the creation of new value in society, delivered by a network of relationships between firms that make up the project coalition (Pryke, 2009). This value includes time, costs and quality. In SCM, all supply chain actors need to be able to make a full contribution to ensure that the client's needs are fulfilled and that value creation is maximised (Broft et al., 2016). This implies a collaborative customer focus and a higher quality of the delivery of each subprocess. SCM also encourages integrated project delivery (IPD) or common product development as suppliers are involved early in the process and play an important role in the design stage, invited to work on target cost (Anderson, 2006) and to contribute to pre-designed solutions. Target costing is an important aspect of SCM - it is an effective interorganisational management technique that has been used in manufacturing toachieve cost predictability during new product development (Zimina et al., 2012) in a supply chain. It helps to ensure that new products and services meet market-determined prices and provide financial returns (Cooper \&Kaplan, 1999). The value perspective also focuses on SCM's main objective to enhance mutual competitive advantage (Pryke, 2009).

\section{SCM IN CONSTRUCTION FROM A TFV-PERSPECTIVE}

SCM is considered a way of thinking about management and processes, which includes improved relationships, integrated processes and increased customer focus (Pryke, 2009). Integration (or interdependency) and value creation - important aspects of the F- and Vconceptualisations of the production theory - seem to be essential in SCM. Table 2represents the characteristics of SCM in construction from each production perspective, following from Section 3.1, 3.2 and 3.3. The table is descriptive - it decomposes SCM to its constituents and presents them as key principles.

Table 2: The characteristics of SCM in construction from a TFV-perspective

\begin{tabular}{|c|c|c|}
\hline $\begin{array}{l}\text { View on } \\
\text { production }\end{array}$ & Conceptualisation of SCM & Keyprinciples \\
\hline $\begin{array}{l}\text { Common toall } \\
\text { views }\end{array}$ & $\begin{array}{l}\text { Long-term collaborations between } \\
\text { supply chain actors to ensure a } \\
\text { project-exceeding focus and to } \\
\text { create a more permanent } \\
\text { organisation. }\end{array}$ & $\begin{array}{l}\text { - Long-term collaboration with } \\
\text { suppliers. }\end{array}$ \\
\hline Transformation & $\begin{array}{l}\text { Managing all subprocesses, } \\
\text { subcontracted to different suppliers, } \\
\text { and logistics needed to perform a } \\
\text { production process. Relationships } \\
\text { between subprocesses are } \\
\text { acknowledged, but remain } \\
\text { transactional. }\end{array}$ & 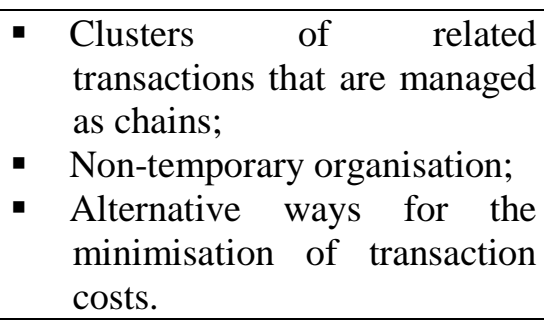 \\
\hline Flow & A supply chain, encompassing all & - Focus on overall efficiency; \\
\hline
\end{tabular}




\begin{tabular}{|c|c|c|}
\hline & $\begin{array}{l}\text { the subprocesses is conceptualised } \\
\text { as a production flow. Coordination } \\
\text { between subprocesses is important } \\
\text { in order to boost total process } \\
\text { efficiency and effectiveness across } \\
\text { members of the supply chain. This } \\
\text { involves the acknowledgement of } \\
\text { interdependencies between } \\
\text { subprocesses, and includes } \\
\text { integration. This integration } \\
\text { between subprocesses focuses on } \\
\text { the overall efficiency of the entire } \\
\text { supply chain. }\end{array}$ & $\begin{array}{l}\text { Lead time reduction through } \\
\text { the elimination of waste and } \\
\text { the reduction of variability; } \\
\text { - Product-focus (including the } \\
\text { subprocesses organised } \\
\text { around this product). }\end{array}$ \\
\hline Value & $\begin{array}{l}\text { Ensuring that the client's needs are } \\
\text { fulfilled and that value creation is } \\
\text { maximised - all supply chain actors } \\
\text { need to be able to make a full } \\
\text { contribution. This implies a } \\
\text { collaborative customer focus and a } \\
\text { higher quality of each delivered } \\
\text { subprocess. }\end{array}$ & $\begin{array}{l}\text { - Fulfilment of customer } \\
\text { requirements for the product } \\
\text { regarding time, cost and } \\
\text { quality; } \\
\text { A higher quality of each } \\
\text { delivered sub-product; } \\
\text { - Collaborative customer focus; } \\
\text { - Common product } \\
\text { development; } \\
\text { - Supplier prequalification and } \\
\text { early supplier involvement; } \\
\text { Mutual competitive } \\
\text { advantage. }\end{array}$ \\
\hline
\end{tabular}

\section{CONCLUSION}

Production management in construction is moving away from conventional construction management. The correctives to this model have been explicitly or implicitly based on flow and value principles. SCM is often presented as suitable for efficient management of construction production. Its successful implementation in the industry, however, remains limited to the improvement of logistics and inventory, whereas in some industries SCM has become a central strategy, dealing with total business excellence.

This paper presents an analysis of SCM in construction from a production perspective. Important aspects of the $\mathrm{F}$ - and $\mathrm{V}$-conceptualisations of the production theory have already been implicitly acknowledged in SCM, however, this paper provides the reader with a more descriptive and explicit conceptualisation of SCM from each production perspective and reflects the difference between each view on these conceptualisations.

Despite that all three SCM conceptualisations include long-term collaborations with suppliers, clustering subprocesses around a supply chain, each view on production emphasises a different aspect of SCM. Where transformation focuses on the transactional relationship between subprocesses (or in other words, suppliers) and focuses on cost minimisation accordingly, flow acknowledges the interdependency through the integration of processes and the creation of relationships, and value acknowledges the delivery of quality as a result of each subprocess. The differences have been presented in 
Section 3.4 - Table 2 also describes the associated key principles. In this way, the paper creates a better understanding of the SCM concept and suggests that for SCM to succeed in the best possible manner, all three views need to be considered and promoted. This understanding could be used prescriptively in the further development of SCM in construction, and added clarity of the concept might subsequently offer opportunities for successful implementation of SCM at the lower tiers of the construction supply chain.

\section{REFERENCES}

Akintan, O.A. and Morledge, R. (2013), "Improving the collaboration between main contractors and subcontractors within Traditional Construction Procurement", Journal of Construction Engineering, Article ID 281236.

Anderson, S.W. (2006), "Managing costs and cost structure throughout the value chain: research on strategic cost management", Handbooks of Management Accounting Research, Vol. 2, pp. 481-506.

Arditi, D. and Chotibhongs, R. (2005), "Issues in subcontracting practice", Journal of Construction Engineering and Management, Vol. 131 (8), pp. 866-876.

Ballard, G. (2005), "Construction: One type of project production system", in: Proceedings IGLC-13, July, Sydney, Australia.

Ballard, G. and Howell, G.A. (1998), "What kind of production is construction?", in: Proceedings 6th Annual Lean Construction Conference (IGLC-6), 13-15 August 1998, Guarujá, Brazil.

Bemelmans, J., Voordijk, H. and Vos, B. (2012), "Supplier-contractor collaboration in the construction industry: A taxonomic approach to the literature of the 2000-2009 decade", Engineering, Construction and Architectural Management, Vol. 19 (4), pp. 342-368.

Berliner C. and Brimson, J.A. (1988), Cost Management for Today's Advanced Manufacturing, Harvard Business School Press, Boston.

Broft, R.D. (2017), "Exploring the application of lean principles to a construction supply chain", in: Proceedings of the $25^{\text {th }}$ Annual Conference of the International Group for Lean Construction (IGLC), 9-12 July, Heraklion, Crete, Greece.

Broft, R.D., S. Badi and Pryke, S. (2016), "Towards SC Maturity in Construction”, Built Environment Project and Asset Management, Emerald, Special Issue.

Burgess, K., Singh, P.J. and Koroglu, R. (2006), "Supply chain management: a structured literature review and implications for future research", International Journal of Operations \& Production Management, Vol. 26 (7), pp. 703-729.

Christopher, M. (2005),Logistics and Supply Chain Management: creating value-adding networks, Pearson Education, Harlow.

Clarke, L. and Herrmann, G. (2004), "Cost vs. production: disparities in social housing construction in Britain and Germany", Construction Management and Economics, Vol. 22 (5), pp. 521-532.

Cooper, R.S. and Kaplan, R. (1999), Design of Cost Management Systems: Text-Cases and Readings, Prentice, Upper Saddle River, NJ. 
Dainty, A.R.J., Briscoe, G.H. and Millett, S.J. (2001), "New perspectives on construction supply chain integration", Supply Chain Management: An international Journal, Vol. 6 (4), pp. 163-173.

Dubois, A. and Gadde, L.E. (2000), "Supply strategy and network effects - purchasing behaviour in the construction industry", European Journal of Purchasing \& Supply Management, Vol. 6 (3-4), pp. 207-215.

Ellram, L.M. and Cooper, M.C. (2014), "Supply Chain Management: It's all about the journey, not the destination", Journal of Supply Chain Management, Vol. 50 (1), pp. 8-20.

Elfving, J. and Ballard, G. (in press), "Supplier Development in the Construction", Journal of Purchasing and Supply Management.

Eriksson, P.E. (2015), "Partnering in engineering projects: four dimensions of supply chain integration",Journal of Purchasing and Supply Management, Vol. 21, pp. 38-50.

Gadde, LE. and Dubois, A. (2010), "Partnering in the construction industry - Problems and opportunities", Journal of Purchasing and Supply Management, Vol. 16 (4), pp. 254-263.

Gilbreth, F.B. and Gilbreth, L.M. (1922), "Process Charts and their Place in Management", Mechanical Engineering, January, pp. 38-41.

Gosling, J., Towill, D.R., and Naim, M.M. (2012), "Learning how to eat an elephant: implementing supply chain management principles", Proceedings of the 28th Annual ARCOM Conference, 3-5 September, Edinburgh, UK.

Green, S.D., Fernie, S. and Weller, S. (2005), "Making sense of supply chain management: a comparative study of aerospace and construction", Construction Management and Economics, Vol. 23 (6), pp. 579-593.

Grubbström, R.W. (1995), "Modelling production opportunities - a historical overview",International Journal of Production Economics, Vol. 41, pp, 1-14.

Hopp, W. and Spearman, M. (1966), Factory Physics: Foundation of Manufacturing Management, Irwin/McGraw-Hill, Boston.

Kale, S. and Arditi, D. (2001), “General contractors' relationships with subcontractors: A strategic asset", Construction Management and Economics, Vol. 19 (5), pp. 541-549.

Koskela, L. (1999), "Management of Production in Construction: A Theoretical View", in: $7^{\text {th }}$ Annual Conference of the International Group for Lean Construction, 26-28 July, Berkeley, California, USA.. (Unpublished)

Koskela, L. (2000), An exploration towards a production theory and its application to construction, VTT Publications, Finland.

Krajewski, L. J., Ritzman, L. P., and Malhotra, M. K. (2007), Operations Management Processes and Value Chains, Upper Saddle River: Prentice Hall.

Lambert, D.M., Cooper, M.C. and Pagh, J.D. (1998), "Supply chain management: Implementation issues and research opportunities", International Journal of Logistics Management, Vol. 9 (2), pp. 1-19.

Luhtala, M., Kilpinen, E., and Anttila, P. (1994), LOGI Managing Make-to-Order Supply Chains, Report, Helsinki University of Technology, Finland. 
Mentzer, J.T., DeWitt, W., Keebler, J.S., Min, S., Nix, N.W., Smith, C.D., and Zachariah, Z.G. (2001), "Defining supply chain management", Journal of Business Logistics, Vol. 22 (2), pp. 1-25.

Oxford Dictionaries (2018), https://en.oxforddictionaries.com/definition/production.

Pasquire, C., Sarhan, S., and King, A. (2015), "A critical review of the safeguarding problem in construction procurement: unpicking the coherent current model", in: $23 \mathrm{rd}$ Annual Conference of the International Group for Lean Construction, pp. 308-318.

Pryke, S. (2009), Construction Supply Chain Management: Concepts and Case Studies, Wiley-Blackwell, Oxford.

Shingo, S. (1988), Non-stock production, Productivity Press, Cambridge, MA.

Souza de Souza, D.V. (2015), A conceptual framework and best practices for designing and improving construction supply chains, $\mathrm{PhD}$ thesis, University of Salford.

Tam, V.W., Shen, L.Y., and Kong, J.S. (2011), "Impacts of multi-layer chain subcontracting on project management performance", International Journal of Project Management, Vol. 29 (1), pp. 108-116.

Tavistock Institute (1966), Interdependence and uncertainty: A study of the building industry, Tavistock Publications, London.

Vrijhoef, R. (2011), Supply Chain Integration in the building industry, PhD thesis, Delft University Press.

Vrijhoef, R. and Koskela, L. (2000), "The four roles of supply chain management in construction", European Journal of Purchasing \& Supply Management, Vol. 6 (3-4), pp. 169-178.

Williamson, O.E. (2008), "Outsourcing: transaction cost economics and supply chain management”,Journal of Supply Chain Management, Vol. 44 (2), pp. 5-16.

Zimina, D., Ballard, G. and Pasquire, C. (2012), "Target value design: using collaboration and a lean approach to reduce construction cost", Construction Management and Economics, Vol. 30 (5), pp. 383-398. 